2002s-26

\title{
Restructuring and Economic Performance: The Experience of the Tunisian Economy
}

Sofiane Ghali, Pierre Mohnen

Série Scientifique

Scientific Series

CI RANO 


\section{CIRANO}

Le CIRANO est un organisme sans but lucratif constitué en vertu de la Loi des compagnies du Québec. Le financement de son infrastructure et de ses activités de recherche provient des cotisations de ses organisationsmembres, d'une subvention d'infrastructure du ministère de la Recherche, de la Science et de la Technologie, de même que des subventions et mandats obtenus par ses équipes de recherche.

CIRANO is a private non-profit organization incorporated under the Québec Companies Act. Its infrastructure and research activities are funded through fees paid by member organizations, an infrastructure grant from the Ministère de la Recherche, de la Science et de la Technologie, and grants and research mandates obtained by its research teams.

\section{Les organisations-partenaires / The Partner Organizations}

-École des Hautes Études Commerciales

-École Polytechnique de Montréal

-Université Concordia

-Université de Montréal

-Université du Québec à Montréal

-Université Laval

-Université McGill

-Ministère des Finances du Québec

-MRST

-Alcan inc.

- AXA Canada

-Banque du Canada

-Banque Laurentienne du Canada

-Banque Nationale du Canada

- Banque Royale du Canada

- Bell Canada

- Bombardier

- Bourse de Montréal

-Développement des ressources humaines Canada (DRHC)

-Fédération des caisses Desjardins du Québec

-Hydro-Québec

-Industrie Canada

-Pratt \& Whitney Canada Inc.

-Raymond Chabot Grant Thornton

-Ville de Montréal

(C) 2002 Sofiane Ghali et Pierre Mohnen. Tous droits réservés. All rights reserved. Reproduction partielle permise avec citation du document source, incluant la notice (C).

Short sections may be quoted without explicit permission, if full credit, including (C) notice, is given to the source.

Les cahiers de la série scientifique (CS) visent à rendre accessibles des résultats de recherche effectuée au CIRANO afin de susciter échanges et commentaires. Ces cahiers sont écrits dans le style des publications scientifiques. Les idées et les opinions émises sont sous l'unique responsabilité des auteurs et ne représentent pas nécessairement les positions du CIRANO ou de ses partenaires.

This paper presents research carried out at CIRANO and aims at encouraging discussion and comment. The observations and viewpoints expressed are the sole responsibility of the authors. They do not necessarily represent positions of CIRANO or its partners.

\section{ISSN 1198-8177}




\title{
Restructuring and Economic Performance: The Experience of the Tunisian Economy*
}

\author{
Sofiane Ghali $\dot{t}^{\dagger}$ and Pierre Mohnen ${ }^{\dot{*}}$
}

\section{Résumé / Abstract}

Cette étude cherche à identifier les sources d'avantage comparatif et les goulots d'étranglement en Tunisie. En utilisant un modèle d'analyse d'activités et des données annuelles de tableaux entrée-sortie et de dotations en facteurs, cette étude détermine l'évolution du potentiel de l'économie tunisienne entre 1983 et 1996 et les améliorations que pourrait y apporter le programme de mise à niveau industriel introduit en 1996. L'analyse montre aussi s'il existe des carences de différents types de main-d'œuvre, en particulier du travail qualifié.

This paper aims at identifying the sources of comparative advantage and the bottlenecks of the Tunisian economy. By using an activity analysis model and yearly data on the input-output structure and the factor endowments, the paper determines the evolution of the potential of the Tunisian economy between 1983 and 1996 and some of its key aspects that the industrial restructuring program of 1996 could improve or reinforce. The analysis sheds light on the scarcity of various types of labor, in particular of qualified labor.

Mots-clés : Tunisie, analyse d'activités, travail qualifié, programme d'ajustement structurel

Keywords: Tunisia, activity analysis, qualified labor, industrial restructuring program

\footnotetext{
* Corresponding author: Pierre Mohnen,MERIT, University Maastricht, P.O. Box 6166200 MD Maastricht, The Netherlands E-mail: p.mohnen@ merit.unimaas.nl

This work was supported by the Social Sciences and Humanities Research Council of Canada. We thank Thijs ten Raa for stimulating discussions. Very helpful remarks were also received by participants at the MEEA conference in London and the ERF conference in Cairo and by an anonymous reader.

${ }^{\dagger}$ Faculté des Sciences Economiques et de Gestion de Tunis, Université de Tunis-El Manar

" University Maastricht, Université du Québec à Montréal, CIRANO and MERIT
} 


\section{INTRODUCTION}

In mid-1995 Tunisia made the strategic choice of becoming the first country in the Middle East and North African region to sign a Free Trade Agreement (FTA) with the European Union (EU). In 1996, the authorities launched a vast industrial restructuring program ("programme de mise-à-niveau") aimed at helping Tunisian firms bridge the gap between their current performance and the benchmark performance of their trading partners by upgrading productive capacity and human capital. The program targeted to restructure 2000 enterprises by the end of 2001 out of 4000 potential candidates.

This program followed the structural adjustment program that was put into place in 1986 and was designed to progressively dismantle the many controls on resource allocation, to privatize state-controlled enterprises, and to moderate the growth in aggregate demand. In the 1980s Tunisia was a country plagued with unemployment as high as $15 \%$, a budgetary deficit of $5.2 \%$, a continuously deteriorating current account deficit, and a large and inefficient public sector, in other words, dim prospects for future development.

We shall analyze the evolution of the potential of the Tunisian economy from 1983 to 1996 using a general equilibrium model. By using an activity analysis model and yearly data on the input-output structure of the Tunisian economy and its endowments of labor and capital, we shall determine by how much each year the Tunisian economy could have increased its level of domestic final demand expenditures (current consumption and investments in future consumption) and determine its weakness and potentialities that the program of "mise-à-niveau" could solve or reinforce. 
Labor is subdivided into five levels of qualification, where the bottom three (manual workers, machine operators, and foremen) are assimilated to unqualified labor and the top two (technicians and engineers/administrators) correspond to qualified labor. The model allows us to measure the scarcity of each type of labor. The model also determines the sectors where Tunisia has a comparative advantage in tradable commodities. We shall compare the structure and the performance of the Tunisian economy before and after the structural adjustment program of 1986.

In the modern theory of economic growth, research capital, and human capital play a central role (see Lucas (1988), Romer (1990) and Grossman and Helpman, (1991)). Empirical studies, mostly confined to countries of the OECD area, have shown that indeed research and development earn a high rate of return ( see the surveys by Griliches (1995), Mohnen (2001). As reliable data on R\&D are lacking for Tunisia, we cannot test the effect of innovation on the growth performance in Tunisia. Regarding human capital, generally proxied by education, case studies are more convincing than econometric studies (see Schultz (1999) and Pissarides (2000)). Estimates are often insignificant and sensitive to variations in measurement and specification (see Topel (1999), Krueger and Lindahl (2001) and Kalatzidakis et al. (2001)). For Tunisia, instead of using data on labor by level of education, we use data on labor by type of qualification, which can be considered as the output of education and job training. We can therefore evaluate the marginal social value of qualified versus unqualified labor and their respective contributions to output growth. 
The paper is organized as follows. In section 2, we present our activity analysis model and explain its main properties. In section 3, we retrace the evolution of factor utilization in Tunisia between 1983 and 1996. In section 4, we analyze the evolution of optimal factor allocations and corresponding factor prices before and after the structural adjustment program. In particular, we compute a rate of return on qualified labor. In section 5, we report the results of a series of experiments with different scenarios to assess the sensitivity of our results. We conclude in section 6 by summarizing the main conclusions and by drawing some lessons from the Tunisian example with the structural adjustment program. The data sources and constructions are described in an appendix. 


\section{THE MODEL}

Suppose a social planner who knows the production structure, technologies, preferences and factor endowments of his economy, and wants to allocate resources and production in such a way as to maximize the level of domestic final demand, which thus includes present consumption and investment towards future consumption, both public and private. We consider a small open economy where we allow the trade deficit to equal the observed deficit.

Formally, the efficient state of the economy is obtained by solving the following linear programming problem:

$\max _{t, s, g}(D F D) t \quad$ subject to the following constraints :

$$
\begin{aligned}
\left(V^{\prime}-U\right) s & \geq f t+J g \\
\left(L_{1}+L_{2}+L_{3}+L_{4}+L_{5}\right)^{\prime} s+\left(l_{1}+l_{2}+l_{3}+l_{4}+l_{5}\right) t & \leq N_{1}+N_{2}+N_{3}+N_{4}+N_{5} \\
\left(L_{2}+L_{3}+L_{4}+L_{5}\right)^{\prime} s+\left(l_{2}+l_{3}+l_{4}+l_{5}\right) t & \leq N_{2}+N_{3}+N_{4}+N_{5} \\
\left(L_{3}+L_{4}+L_{5}\right)^{\prime} s+\left(l_{3}+l_{4}+l_{5}\right) t & \leq N_{3}+N_{4}+N_{5} \\
\left(L_{4}+L_{5}\right)^{\prime} s+\left(l_{4}+l_{5}\right) t & \leq N_{4}+N_{5} \\
L_{5}{ }^{\prime} s+l_{5} t & \leq N_{5} \\
\hat{K} \hat{C} s & \leq K \\
-\pi^{\prime} g & \leq D \\
s & \geq 0
\end{aligned}
$$


where

$D F D=\tilde{P^{\prime}} f+\tilde{w^{\prime} l}$

$t=($ scalar $)$ level of domestic final demand;

$s=(\mathrm{nx} 1)$ vector of activity levels, where $\mathrm{n}$ is the number of sectors;

$g=\left(\mathrm{m}_{\mathrm{T}} \mathrm{x} 1\right)$ vector of net exports, where $\mathrm{T}$ indices tradable commodities;

$V=$ make matrix (nxm), indicating how much of each commodity is produced in each sector;

$U=$ use matrix ( $\mathrm{mxn}$ ), indicating how much of each commodity is used in each sector as

intermediate inputs;

$J=\left(\mathrm{nxm}_{\mathrm{T}}\right)$ matrix selecting the tradables;

$L_{i}=$ employment of labor type $\mathrm{i}, \mathrm{i}=1, \ldots ., 5$, where manual workers/trainees are indexed by 1 , machine operators by 2 , foremen by 3 , technicians by 4 , and engineers/administrators by 5 ;

$N_{i}=$ labor force of type $\mathrm{i}, \mathrm{i}=1, \ldots, 5$;

$K=(\mathrm{nx} 1)$ vector of available capital stocks in each sector;

$C=(\mathrm{nx} 1)$ vector of capacity utilization rates;

$\pi=\left(\mathrm{m}_{\mathrm{T}} \mathrm{x} 1\right)$ vector of world prices for tradable commodities relative to a domestic - final - demand - weighted average of world prices;

$D=$ observed trade deficit $=-\pi^{\prime}\left(V^{\prime} e-U e-f\right)_{T}$

$e=$ unity vector of appropriate dimension;

$\wedge$ diagonalization operator applicable to a column vector;

$\tilde{P}=(\mathrm{mx} 1)$ vector of observed commodity prices, where $\mathrm{m}$ is the number of commodities;

$f=(\mathrm{mx} 1)$ vector of domestic final demand;

$l_{i}=(5 \times 1)$ vector of employment in the non - business sector for each labor type;

$\tilde{w}=(5 \times 1)$ vector of annual labor earnings per worker by qualification in the non - business sector.

The decision variables are the level of domestic final demand $(\mathrm{t})$, the sectoral activity levels (s) and net exports (g). They are determined so as to maximize domestic final demand subject to three sets of constraints. The first set are the commodity balances (1) which stipulate that net production in each sector has to be sufficient to satisfy domestic final demand and net exports. The second set, (2) to (7), states that the inputs used in each sector may not exceed total disposable inputs. Capital is taken to be sector-specific. In 
other words, we assume putty-clay technologies. Once installed in one sector, capital cannot be disassembled and affected somewhere else. A sectoral capital constraint is binding when a sector reaches full capacity utilization. For labor, we distinguish five different types, each corresponding to a certain level of qualification and expertise. Workers can always be affected to jobs requiring lower but not higher qualifications. For example, the work requiring administrators and engineers can only be fulfilled by workers possessing their type of qualifications whereas the work normally done by technicians can also be fulfilled by engineers. Part of the labor force is affected to the non-business sector, which essentially comprises services directly consumed by final demand (government services, services provided by non-profit institutions). The last constraint (8) posits that the trade deficit at optimal activity levels may not exceed the observed trade deficit. To increase their level of consumption, Tunisians can import from abroad, but only up to a certain level, which is conservatively taken to be the observed trade deficit. Without constraint (8), Tunisia could reach an infinite value for its objective function by importing without limits. ${ }^{1}$ The assumption of a small open economy with exogenous world prices for the tradable commodities is not unrealistic in the case of Tunisia.

The observed activity levels correspond to the following values: $t=1, s=e$, and $D=-\pi^{\prime}\left(V^{\prime} e-U e-f\right)_{T}$. The observed state of the economy is thus our point of reference. Efficiency derives from full capacity utilization, optimal factor allocations across sectors, and international specialization. Variations of this model appear in ten Raa and Mohnen

\footnotetext{
${ }^{1}$ The observed trade balance is introduced as a factor of production, as in the work by Diewert and
} 
(1994), ten Raa (1995) and ten Raa and Mohnen (2000). This model could also be seen as a macroeconomic DEA ("data envelopment analysis") model, that determines the economy's frontier given its technologies, preferences and endowments (see ten Raa and Mohnen (2000) for more discussion on this point). But it is not a benchmarking exercise with respect to a best technology as most DEA analyses are. It should also be noticed that our analysis is of a short-term nature, in the sense that the optimal resource allocation that underlies the optimal solution of our activity analysis is dependent on the observed levels of technology. We do not model technological change nor changes in preferences and endowments.

The decomposition of labor into five levels of qualification sheds some light onto the kind of labor shortages Tunisia has been facing and on the returns to innovation.

The solution of the linear program above yields not only a picture of resource allocations in an efficient economy, but also of the prices sustaining such an equilibrium resource allocation. To see this, consider the dual programming problem

$$
\begin{aligned}
& \min _{p, w, r, \varepsilon} w^{\prime} N+r^{\prime} K+\varepsilon D \text { subject to the following constraints } \\
& p^{\prime}\left(V^{\prime}-U\right) \leq w^{\prime} L^{\prime}+r^{\prime} \hat{K} \hat{c} \\
& p^{\prime} f+w^{\prime} l=D F D \\
& p^{\prime} J=\varepsilon \pi \\
& p \geq 0, \quad w_{5} \geq w_{4} \geq w_{3} \geq w_{2} \geq w_{1} \geq 0, \quad r \geq 0, \quad \varepsilon \geq 0
\end{aligned}
$$

Morrison (1986) and Kohli (1991). 
where $\mathrm{p}, \mathrm{w}, \mathrm{r}$ and $\varepsilon$ are respectively the shadow prices of commodities, of the five types of labor, of the sectoral capital stocks, and of the trade deficit. By the theorem of complementary slackness, a shadow price is positive only if the corresponding constraint in the primal is binding. The shadow prices $\mathrm{w}$ and $\mathrm{r}$ denote the marginal values of an additional unit of the respective inputs. If at a certain level of qualification the labor constraint is tight, it earns a markup over the previous level of qualification. A sector with less than full capacity utilization earns a zero rate of return on a marginal capital investment, for the very simple reason that it is in no excess demand, as unused capital is still available. The shadow price $\varepsilon$ of the trade balance indicates the marginal value in terms of attainable domestic final demand of an additional allowed dinar of trade deficit. By the complementary slackness conditions, it can also be said that a sector is active only if it makes no loss. The inequalities (9) indicate that at the optimal solution of the linear program the prices of active sectors equal average cost, and hence that the optimal solution can be obtained as a competitive equilibrium. Condition (10) is a normalization condition akin to the choice of a numeraire. By equality (11) domestic prices for tradable commodities may differ from world prices only by a certain constant $\varepsilon$, which can be interpreted as the exchange rate compatible with the purchasing power parity. All quantities are expressed in constant dinars, except labor, which is denoted in man-years. Hence, all shadow prices are relative constant prices, except the shadow prices of labor which are in constant dinars per man-year. 


\section{THE DATA}

The data on which we base our analysis are described in appendix 2 . The concordance between industry and commodity classifications is given in appendix A. As table 1 shows, the unemployment rate has always been much higher for the qualified workers (levels 4 and 5) than for the low qualified workers (levels 1 to 3). For instance, in 1990, $28.7 \%$ of the qualified workers were out of work compared to $13.9 \%$ of the less-qualified workers. From 1987 onwards, about the time when Tunisia adopted the structural adjustment program, we notice first an increase in the overall rate of capacity utilization, and second a decrease in the unemployment rate for the qualified workers and an increase for the less-qualified workers. We notice a persistent shift from manual workers (level 1) towards machine operators (level 2) over the whole period. Low qualified workers make up almost $90 \%$ of the total work force. There was no major shift of employment composition among the qualified workers (levels 4 and 5). This high level of unemployment for qualified workers might seem unreasonable for a country that devotes a significant proportion of its national resources to human capital accumulation. It can be explained by the structure of the Tunisian economy. According to a World Bank study (2000, Vol II, table 2.3, p.6), in 1996, $82.4 \%$ of the Tunisian enterprises employed less than 6 workers while only $1.6 \%$ employed more than 100 workers and only a dozen firms more than 500 workers. We shall now examine what would have been the optimal allocation of resources in Tunisia for each year between 1983 and 1996.

\footnotetext{
<insert somewhere here table 1 >
} 


\section{RESULTS}

\subsection{Optimal resource allocation}

In table 2 we present the optimal sectoral activities, i.e. the optimal allocation of resources in Tunisia, for five selected years. Activity levels with a star indicate full capacity utilization. For instance, in 1984 agriculture and fishing should have operated at $34 \%$ above the observed activity level under optimal allocation of resources. But even at this activity level, the sector would still not have operated at full capacity. Food processing would in the same year have reached its full capacity at $125 \%$ above observed activity. Full capacity utilization would also have been reached by construction materials and glass, mining, the hydrocarbons industry, transport and commerce, hotel and tourism, and other services. Textile and leather and other manufacturing had better not been activated.

Glancing at table 2 we notice that textile and leather, and other manufacturing had most of the time better been disactivated. Electricity, water, and construction and public work produce non-tradable commodities. They always need to be activated as their commodities are needed as inputs in other sectors and cannot be imported. They never reach full capacity though, as their production surplus cannot be exported. Agriculture and fishing could have increased their level of operation but not at full capacity. They serve as a cushion sector to hire the labor force in periods of close to full capacity in the other sectors. The other sectors, food processing, construction material and glass, mechanical and electrical goods, mining, production of hydrocarbons, transport and 
communications, hotels and tourism, and other services were ripe for operation at full capacity levels.

<insert somewhere here table $2>$

\subsection{Tunisia's comparative advantage}

Table 2 also reveals the location of Tunisia's comparative advantage, i.e. the sectors where Tunisia could specialize and be a net exporter. In the second column for each year of table 2 we present a sectoral breakdown of all positive net exports at the optimal allocation of resources. We notice that the strongest potential earners of foreign exchange are hotel and tourism and other services (including trade and financial services), and to a lesser extent transport and communication, construction material and glass, and what we could call the food conglomerate (agriculture, fishing, and food processing). At the optimal solution, the first two make up for at least two thirds of net exports, transport and communications account for about $10 \%$ of total positive net exports, the food conglomerate for $15 \%$ to $20 \%$, and construction material and glass show a steady net export of $3 \%$ to $4 \%$ of the total. There were no major shifts in comparative advantage over the years. The sector mechanical and electrical goods should always have been activated at full capacity but not for generating net exports. So were most of the time mining and production of hydrocarbons. Here and there they could achieve some net exports, but they are not real sectors of comparative advantage. They are merely sectors needed to sustain economic activity. 
It is interesting to compare the actual and the optimal specialization of the Tunisian economy in foreign trade (columns 2 and 3 for each year). Textiles and mining show some foreign trade where there should be none, according to our analysis. In transport and communications, and in hotel and tourism there is more trade than we would desire. In other services instead there is insufficient trade. In food processing, construction materials, and glass and hydrocarbons actual trade patterns tend to move in the right direction. The most impressive evolution is that of net exports in hydrocarbons, which steadily declined and ceased to be a net export at the end of our sample as predicted by our analysis of comparative advantage.

\subsection{Efficiency and shadow prices}

According to our results, Tunisia could have increased its level of domestic final demand, our measure of national well-being, by anywhere between $13 \%$ and $24 \%$ over the various years (see first column of table 3). The higher the expansion factor, the farther away the economy was from its optimal factor allocation, hence the less efficient it was. If we take the years before and after the structural adjustment program of 1986, we notice that the economy moved closer to its efficiency frontier between 1989 and 1992, but turned less efficient again from 1993 on, but not to the levels prior to 1986. This result is in line with the overall evolution of the rate of capacity utilization.

In our model labor is mobile across sectors and gets assigned first to the sector with the greatest value added until that sector reaches its full capacity, then to the next sector with 
the greatest value added until this one reaches its full capacity and so on. The wage rate for a certain type of labor is thus determined by its marginal productivity in the last sector that is activated. The marginal social value of workers of different qualifications is reflected in their shadow wages (table 3). In 1983, the availability of one more worker in the economy could increase its well-being by 1,610 dinars per year. The fact that higher qualified workers did not potentially earn more than low-qualified workers is equivalent to saying that there was no room for a wage markup for higher qualifications. This is indeed what we would expect given the higher unemployment rate for high-qualified workers. Only in 1988 and then again in 1994, 1995 and 1996 was there a certain shortage of the L2 type of labor compared to the L1 type. Except for the years 1988 and 1989, we notice a general upward trend in labor value. In 1996, a worker's contribution to the economy in categories 2 to 5 was worth 3,410 dinars per year.

As capital is sector-specific, sectors can expand only up to their full capacity. All sectors with full capacity earn a positive shadow price for their capital stock. Those are the sectors that were are marked by a star in table 2 . The sectors which are either completely idle or else activated at less than full capacity earn no marginal return on their capital stock. The weighted average rate of return on physical capital has been dropping from $22 \%$ in 1983 to $8 \%$ in 1991, and has afterwards risen again to reach $13 \%$ in 1996 . The social return on capital was lower after the structural adjustment program showing that the Tunisian economy invested during this period and reached rates of return closer to the normal rate. From 1992 on, capital became scarcer again, but not to the extent it was in 1983 and 1984. 
The purchasing power parity, i.e. the shadow price corresponding to the trade deficit (the last column in table 3), has moved slightly to the advantage of Tunisia. The lower the domestic prices compared to the world prices, the more a given foreign trade deficit can be converted into higher consumption. In 1983, the domestic price level for tradables was $78 \%$ of the world price. Since then domestic prices have declined (and hence the purchasing power parity has strengthened) to end at 73\% of the world price in 1996.

$<$ insert somewhere here table $3>$

\subsection{Evaluation of the country's wage bill for qualified workers}

If we multiply the number of workers in L4 and L5 by their respective observed wages (in constant dinars), we obtain the wage bill for qualified workers per sector. We divide each industry total by the economy's total to get the decomposition of qualified labor bill by industry. From the figures reported in table 4 we see that in Tunisia the qualified labor bill is mainly concentrated in agriculture, textiles and leather, and other services. In 1996, those three sectors made up almost $64 \%$ of the total qualified labor bill. Its ratio to GDP has been relatively stable over the years, around $6.5 \%$.

$<$ insert table 4 > 


\subsection{Rate of return on qualified workers}

We calculate the rate of return on qualified workers by dividing the difference between the optimal and the observed labor bill for labor categories 4 and 5 by the observed labor bill for those two categories combined:

$$
\mathrm{RRD}=\left(\mathrm{w}_{4} \mathrm{~L}_{4}+\mathrm{w}_{5} \mathrm{~L}_{5}\right) /\left(\mathrm{w}_{4}{ }^{\mathrm{o}} \mathrm{L}_{4}+\mathrm{w}_{5}{ }^{\mathrm{o}} \mathrm{L}_{5}\right)-1
$$

where $\mathrm{w}_{4}$ and $\mathrm{w}_{5}$ are the shadow wage rates and $\mathrm{w}_{4}{ }^{\circ}$ and $\mathrm{w}_{5}{ }^{\circ}$ are the observed wage rates. In this way, we measure the wage premium above the actual wage that each qualified worker commands at the optimal allocation of resources. This rate of return is to be interpreted as a marginal social rate of return, capturing how much the Tunisian economy given its structure of technology, preferences, and factor endowments is able to increase its final demand by investing in one more qualified worker. The figures reported in the bottom row of table 4, which are weighted averages of the sectoral rates of return (with the observed labor costs as weights), indicate that qualified workers earned a negative rate of return throughout the sample period. ${ }^{2}{ }^{3}$ The marginal value of a highly qualified worker did not match its actual wage payment. On average the rate of return was $-47 \%$ before 1990. It rose to $-27 \%$ on average between 1990 and 1996 . The structural

\footnotetext{
${ }^{2}$ We have also regressed TFP growth, with pooled data correcting or not for time and sector dummies, on a constant and the ratio of the wage bill of qualified workers over sales to get an estimate of the rate of return on qualified workers. The rate of return was never significant.

${ }^{3}$ Negative (even significant) rates of return on human capital of the male gender are reported in the literature (for example, Caselli et al. (1996), Kalatzidakis et al. (2001).
} 
adjustment program seems to have had a beneficial effect on the allocative efficiency of qualified labor.

\subsection{Growth decomposition}

In table 5, we decompose the growth rate of the optimal level of domestic final demand into the growth attributable to each factor input. We know from linear programming that the optimal value of the primal equals the optimal value of the dual. The latter can be decomposed into the value attributable to each factor of production: the five types of labor, the physical capital stock, the trade deficit, which can be considered as an input into the production of domestic final demand in an open economy ${ }^{4}$. We have computed the growth rates of optimal domestic final demand and its components over the whole period and the three sub-periods corresponding to successive five-year plans. As table 5 indicates, the pro-competitive and liberalizing structural adjustment program introduced in 1986 obviously lead to a substantial growth in domestic final demand. The major source of growth comes from the increase in the number and rewards of machine operators. However, the improved growth performance of the Tunisian economy between the $6^{\text {th }}$ and the $8^{\text {th }}$ five-year plan is almost entirely due to investment in physical capital.

$<$ insert table $5>$

\footnotetext{
${ }^{4}$ Since t DFD $=w^{\prime} N+r^{\prime} K+\varepsilon D, \mathrm{~d}(\mathrm{t}$ DFD $) /(\mathrm{t}$ DFD $)=\left[\mathrm{w}^{\prime} \mathrm{N} / \mathrm{t} \mathrm{DFD}\right] \mathrm{d}\left(\mathrm{w}^{\prime} \mathrm{N}\right) /\left(\mathrm{w}^{\prime} \mathrm{N}\right)+$ $\left[\mathrm{r}^{\prime} \mathrm{K} / \mathrm{t} \mathrm{DFD}\right] \mathrm{d}\left(\mathrm{r}^{\prime} \mathrm{K}\right) /\left(\mathrm{r}^{\prime} \mathrm{K}\right)+[\varepsilon \mathrm{E} / \mathrm{t} \mathrm{DFD}] \mathrm{d}(\varepsilon \mathrm{E}) /(\varepsilon \mathrm{D})$.
} 


\section{SENSITIVITY ANALYSIS}

In order to evaluate to what extent our results depend on some critical assumptions underlying the model or the data construction, we have made a number of experiments. To these we now turn.

\subsection{Mobility of capital}

If we let capital be completely mobile across sectors rather than be sector-specific, the economy becomes much more flexible in its allocation of resources. It can then completely specialize in its sectors of comparative advantage, export those commodities and from the export proceeds import the other needed commodities for production and consumption. The prices of the tradables sustaining the equilibrium drop sharply and those of the non-tradables increase as they now become bottlenecks. The optimal reachable level of domestic final demand is much higher (around 200\%). The shadow wage of the most skilled member of the labor force increases.

\subsection{Unemployment by qualifications}

We have experimented with three distributions of unemployment across qualifications, a declining rate of unemployment as we move to higher categories of specialization, an increasing rate of unemployment and a U-shaped distribution with higher unemployment rates at both ends. We have made sure that the weighted average unemployment rate is always consistent with the aggregate observed rate. The more we move towards lower 
levels of unemployment for a given category, the more the shadow wage in that category goes up, as we would expect.

\subsection{Mobility of labor}

We have assumed that a worker of higher qualification can always replace a worker of lower qualification, but not the opposite. Given this asymmetry in labor mobility, the wage rates becomes flatter and lower for low levels of qualification, because of more labor abundance. If we make the model more rigid and allow workers to be qualified for their own job only, then we obtain quite a different pattern of shadow wage rates. It is now more likely that each labor qualification experiences some scarcity. We have recalculated the linear program with a uniform rate of unemployment of $15 \%$ across labor

qualifications. The interesting finding is the evolution of labor scarcity over time. Manual workers, machine operators and foremen earn a non-zero wage rate. Foremen earn the most. However, the two most qualified categories of labor, engineers and administrators are all the time in excess supply. This experiment confirms that the most qualified members of the workforce are in relative abundance. Their negative rate of return shows that workers of the two most qualified labor categories get paid above their marginal social value.

\subsection{Rate of capacity utilization}

We have experimented with different levels of uniform rates of capacity utilization across all sectors. As the overall rate of utilization increases more sectors become active. If we let the rates differ across sectors, some sectors can expand more than others but, by and 
large, the resource allocation across sectors remains the same. As final demand must move up in the same proportion for all commodities, the expansion of final demand is affected by the differential rates of capacity utilization. The optimal expansion of domestic final demand is more or less determined by a weighted average of the inverse rates of sectoral capacity utilization, where the weights are the capital stock shares. However, the pattern of shadow prices stays pretty stable across the various experiments regarding the sectoral rates of capacity utilization.

To summarize the various experiments, the results are most sensitive to the assumptions made about factor mobility. As we have modeled labor as being partially mobile and capital as being sector-specific, the assumptions regarding unemployment by qualifications have a greater bearing on the results than those made about sectoral capacity utilization. In our preferred scenario where workers of higher qualifications can always do lower qualified jobs, we notice over time some scarcity developing at the level of machine operators but not at higher levels of qualification. If we do not allow downward mobility of labor in the qualification scales, then the scarcity shows up at the level of supervisors. The highest qualified workers, engineers and technicians, were never in short supply. 


\section{CONCLUSIONS}

We have examined the structural evolution of the Tunisian economy from 1983 to 1996. By solving for each year an optimal resource allocation problem, we have located the sources of strength and the bottlenecks apparent in the Tunisian economy and we have assessed the possible effects of the structural adjustment program introduced in 1986.

Hotel and tourism and other services (regrouping among others trade and financial services) are identified as the main sectors of comparative advantage in Tunisia, and to a lesser extent transport and communication, construction material and glass, and the food conglomerate (agriculture, fishing, and food processing). Our analysis reveals that Tunisia reached a higher degree of efficiency in resource allocations during the $7^{\text {th }}$ fiveyear plan of development but that the efficiency took somewhat of a reverse turn after that. Labor demand shifted slightly from lower to higher levels of qualification, raising their shadow wage rates. The highest qualified workers remained in excess supply throughout the period. The rate of return on qualified labor was actually negative but increasing substantially in the second half of our sample period.

The main aim of the structural adjustment program was to make the Tunisian economy more competitive. Indeed, we notice an increase in competitiveness, that would even be more evident if we allowed for more factor mobility. However, competitiveness also operates through learning, reorganization, adoption of new technologies, and innovation so that firms can improve their management, decrease their production costs and come up 
with new products. Statistics reveal a high level of unemployment for highly qualified workers, and our analysis confirms the relative abundance of these types of workers in the Tunisian economy, and hence their low productivity, that is reflected by negative rates of return on qualified labor. The tremendous investments in education and jobtraining, with a budget share amounting to about $6 \%$ of GDP and $17 \%$ of government expenditures, do not come to full fruition if these high-skilled workers remain jobless. The Tunisian government has to put additional efforts in reducing the unemployment of its best workers. Only then can education lead to greater growth contributions. 


\section{Bibliography}

Ben Slama et al. (1996), "Relations technologiques intersectorielles et décomposition des sources de la croissance", cahiers de l'I.E.Q., no. 12.

Caselli, F, Esquivel, G et Lefort, F. (1996), "Reopening the convergence debate: A New Look at Cross-Country Growth Empirics.", Journal of Economic Growth, 1:3, 363-389.

Diewert, W. E. and C. Morrison (1986), “Adjusting output and productivity indexes for changes in the terms of trade", Economic Journal, 96, 659-679.

Griliches, Z. (1995), "R\&D and Productivity: Econometric Results and Measurement Issues", in P. Stoneman (ed.), Handbook of the Economics of Innovation and Technical Change, Blackwell Handbooks in Economics.

Grossman, G. and E. Helpman (1991), Innovation and Growth in the Global Economy. MIT Press, Cambridge.

Institut d'Économie Quantitative (1996), Étude stratégique no. 8, compétitivité, restructuration, diversification et ouverture sur l'extérieur des industries manufacturières et des services, 8622/96.

Institut National de la Statistique, Les comptes de la nation. Various issues.

Kalatzidakis, P., T.P. Mamuneas, A. Savvides, and T. Stengos (2001), " Measures of Human Capital and Nonlinearities in Economic Growth", Journal of Economic Growth, 6, 229-254.

Kohli, U. (1991), Technology, Duality, and Foreign Trade:The GNP Function Approach to Modeling Imports and Exports. University of Michigan Press,Ann Arbor.

Krueger, A. B. and M. Lindahl (2001); "Education for Growth: Why and for Whom?", Journal of Economic Literature, 29, 1101-1136. 
Lakhoua, Fayçal (1998), "The Tunisian experience of "Mise à niveau": Conceptual issues and policy orientations", MDF II, World Bank, Marrakech, September.

Lucas, R. (1988), “On the Mechanics of Economic Development”, Journal of Monetary Economics, 22, 3-42.

Mohnen, P. (2001), "International R\&D Spillovers and Economic Growth ", in Information Technology, Productivity, and Economic Growth: International Evidence and Implications for Economic Development, Matti Pohjola (ed.), Oxford University Press, 2001.

Morrison, C. and B. Talbi (1996), La croissance de l'économie tunisienne en longue période. Centre de développement de l'OCDE.

Nsouli, Saleh M., S. Eken, P. Duran, G. Bell and Z. Yücelik (1993), The Path to Convertibility and Growth. The Tunisian Experience. International Monetary Fund, Occasional Papers 109, Washington D.C.

Pissarides, C. A. (2000), "Human Capital and Growth: A synthesis Report", Technical papers No 168, OECD Development Centre.

Rama, M. (1998), "How bad is unemployment in Tunisia? Assessing labor market efficiency in a developing country", The World Bank Research Observer, 13(1).

Romer, P. (1990), "Endogenous technological change", Journal of Political Economy, 89(5), 71-102.

Schultz, T. P. (1999), "Health and schooling investments in Africa", Journal of Economic Perspectives, 13(3), 67-88.

Ten Raa, T. (1995), Linear Analysis of Competitive Economies. LSE Handbooks in Economics. Prentice Hall-Harvester Wheatsheaf, Hemel Hempstead. 
Ten Raa, T. (1994), "On the methodology of input-output analysis", Regional Science and Urban Economics, 24(1), 135-158.

Ten Raa, T. and P. Mohnen (1994), "Neoclassical input-output analysis", Regional Science and Urban Economics, 24(1), 135-158.

Ten Raa, T. and P. Mohnen (2000), " Neoclassical Growth Accounting and Frontier Analysis : A Synthesis ", CentER Discussion Paper 67.

Topel, R. (1999), "Labor Markets and Economic Growth," in Handbook of Labor Economics. Orley Ashenfelter and David Card (eds). Amsterdam: North Holland. World Bank (2000), Tunisia-Private sector assessment update, meeting the challenge of globalization, report No.20173-TUN, December. 


\section{Appendix I: Nomenclature and symbols}

\begin{tabular}{|l|c|l|}
\hline \multicolumn{1}{|c|}{ Abbreviations } & Commodity code & \multicolumn{1}{c|}{ Industry } \\
\hline Agric \& Fishing & 00 & Agriculture \& Fishing \\
\hline Food process & 10 & Food processing \\
\hline Const material & 20 & Construction materials \& glass \\
\hline Mechan \& Elect & 30 & Mechanical \& Electrical goods \\
\hline Chem \& Rubb & 40 & Chemical \& Rubber products \\
\hline Text \& Leather & 50 & Textile \& Leather products \\
\hline Other Manuf & 60 & Other Manufacturing \\
\hline Mining & 65 & Mining \\
\hline Hydrocarbons & 66 & Hydrocarbons \\
\hline Electricity & 67 & Electricity \\
\hline Water & 68 & Water \\
\hline Construction & 69 & Construction \& Public works \\
\hline Transp \&Comm & 76 & Transport \&Communications \\
\hline Hot \& Tourism & $79+99$ & Hotels \& Tourism \\
\hline & 79 & - hotels, coffees and restaurants \\
\hline & 99 & - tourism and other stays \\
\hline Other Services & 72 & Services \\
\hline & 82 & - commodity trade \\
\hline & 85 & - financial services and insurance \\
\hline & 94 & - other market services \\
\hline & & - non market services \\
\hline
\end{tabular}




\section{Appendix II: The data}

We make use of the annual input-output tables of Tunisia for the years 1983 to 1996 in constant 1990 prices. At the 20 -sector aggregation level, the tables are expressed in market prices and not at factor costs. Indirect taxes and subsidies are thus included in the inter-industry transaction figures. Given the unavailability of labor and capital data at a sufficient level of detail, we are obliged to aggregate our tables from 20 down to 15 sectors and commodities. The "other services" sector regroups the commodities "trade" (72), "financial services and insurance" (82), "other market services" (85) and "nonmarket services" (94), and is made up of sectors (72), (82) and (85). Tourism regroups the commodities "hotels and restaurants" (79), and "tourism and other stays" (99), and represents sector (79). The expenditures of the fake sector "banking services" have been split between the various sectors in proportion to their consumed banking services following Ben Slama et al (1996) ${ }^{5}$.

The V' make matrix is diagonal implying that one sector produces only one commodity and that each commodity is produced by one sector only. Production is measured in terms of commodities and not in terms of sectors. Output includes trade margins, and import figures include import taxes. For three commodities (electricity, water and public work) we observe no imports nor exports. Those three commodities are therefore considered as non-tradables. World prices are measured by a weighted average of the Tunisian export deflators, under the assumption of competitive world prices. Labor is divided into five

\footnotetext{
${ }^{5}$ We have also tried an alternative split of banking services assuming a uniform distribution of those expenditures across all sectors. This construction yielded similar results of the linear program in terms of active sectors and optimal expansion of domestic final demand.
} 
types: manual workers, machine operators, supervisors, technicians and administrators and engineers. Data on employment in the business and the non-business sectors are taken from employment and population surveys conducted by INS (Institut National de la Statistique. Rama (1998, table 2, p. 70) provides figures on the number of unemployed workers registered with "L'Agence Tunisienne de l'Emploi" for three categories, qualified workers, non-qualified workers, and first-job holders. We regard first-job holders as non-qualified workers. Qualified workers are attributed to categories 4 and 5 and the non-qualified workers to the first three categories. The unemployment rate is supposed to be the same for each subcategory. Combining the figures on employed and unemployed workers, we determine the available labor force by category. ${ }^{6}$ The total observed wage bill for all categories of workers is obtained from the national accounts (I.N.S). The spread between the lowest and highest wages (1 to 5) is supposed to be uniformly distributed across the five categories. This hypothesis is by and large consistent with the various estimates of wage differentials by qualification reported by Morrison and Talbi (1996, table 4.8).

We use the capacity utilization rates for manufacturing estimated by l'Institut d'Économie Quantitative (1996). For agriculture and fishing, we assume the rate to be the

\footnotetext{
${ }^{6}$ The number of unemployed in category $\mathrm{i}(\mathrm{i}=1, \ldots, 5)$ is computed as follows:

$U_{i}=\left(\sum_{i=1}^{5} L_{i} /(1-u r)\right) . u r . \alpha_{j} \beta_{i j}$, where L stands for the number of employed workers, ur the economywide unemployment rate, $\alpha_{j}$ is the proportion of the total unemployed in group $\mathrm{j}$ (where $\mathrm{j}$ designates qualified or low qualified workers, see Rama, 1998), and where $\beta_{j i}$ is the proportion of workers of category $i$ in group $j$.
} 
same as for the food sector. For the other non-manufacturing sectors, we take a capital stock weighted average of the rates in the manufacturing sectors. 
Table 1

Labor composition, unemployment rates and capacity utilization rates: 1983-1996.

\begin{tabular}{|c|c|c|c|c|c|c|c|}
\hline & 1983 & 1984 & 1985 & 1986 & 1987 & 1988 & 1989 \\
\hline \multicolumn{8}{|c|}{ Labor composition by qualifications (\%) } \\
\hline L1+l1 & 28.5 & 28.0 & 27.2 & 26.8 & 26.7 & 26.4 & 25.8 \\
\hline $\mathbf{L} 2+12$ & 53.0 & 53.2 & 54.0 & 54.4 & 54.7 & 55.1 & 55.5 \\
\hline $\mathbf{L 3 + 1 3}$ & 8.0 & 7.8 & 8.0 & 8.0 & 7.9 & 8.0 & 7.9 \\
\hline L4+14 & 7.3 & 7.4 & 7.2 & 7.0 & 7.0 & 6.8 & 7.0 \\
\hline L5+15 & 3.4 & 3.6 & 3.7 & 3.8 & 3.8 & 3.8 & 3.8 \\
\hline \multicolumn{8}{|c|}{ Unemployment rates $(\%)$} \\
\hline L1+l1 & 11.9 & 11.2 & 10.9 & 11.6 & 12.4 & 12.7 & 13.4 \\
\hline $\mathrm{L} 2+\mathrm{l} 2$ & 11.9 & 11.2 & 10.9 & 11.6 & 12.4 & 12.7 & 13.4 \\
\hline L3+13 & 11.9 & 11.2 & 10.9 & 11.6 & 12.4 & 12.7 & 13.4 \\
\hline L4+14 & 28.9 & 28.0 & 32.8 & 32.1 & 34.0 & 32.8 & 30.6 \\
\hline L5+15 & 28.9 & 28.0 & 32.8 & 32.1 & 34.0 & 32.8 & 30.6 \\
\hline Average & 13.8 & 13.1 & 13.5 & 14.0 & 15.0 & 15.0 & 15.3 \\
\hline \multicolumn{8}{|c|}{ Overall capacity utilization rates $(\%)$} \\
\hline & 62.0 & 62.0 & 61.0 & 62.0 & 68.0 & 68.0 & 71.0 \\
\hline
\end{tabular}


Table 1 (Con'd)

Labor composition, unemployment rates and capacity utilization rates: 1983-1996.

\begin{tabular}{|c|c|c|c|c|c|c|c|}
\hline & 1990 & 1991 & 1992 & 1993 & 1994 & 1995 & 1996 \\
\hline \multicolumn{8}{|c|}{ Labor composition by qualifications (\%) } \\
\hline $\mathbf{L} 2+\mathbf{1 2}$ & 55.6 & 55.3 & 55.6 & 55.9 & 56.6 & 57.0 & 57.3 \\
\hline L4+14 & 7.0 & 7.0 & 7.3 & 7.2 & 7.2 & 7.2 & 7.2 \\
\hline L5+15 & 3.7 & 3.8 & 3.8 & 3.8 & 3.8 & 3.8 & 3.8 \\
\hline \multicolumn{8}{|c|}{ Unemployment rates $(\%)$} \\
\hline $\mathbf{L} 2+12$ & 13.9 & 14.1 & 15.5 & 14.0 & 14.0 & 14.0 & 14.0 \\
\hline $\mathbf{L 3 + 1 3}$ & 13.9 & 14.1 & 15.5 & 14.0 & 14.0 & 14.0 & 14.0 \\
\hline L4+14 & 28.7 & 28.7 & 28.9 & 28.3 & 28.4 & 28.3 & 28.2 \\
\hline L5+l5 & 28.7 & 28.7 & 28.9 & 28.3 & 28.4 & 28.3 & 28.2 \\
\hline Average & 15.5 & 15.7 & 15.7 & 15.6 & 15.6 & 15.6 & 15.6 \\
\hline \multicolumn{8}{|c|}{ Overall capacity utilization rates $(\%)$} \\
\hline
\end{tabular}

Note: Li: employment of qualification $\mathrm{i}$ in the business sector

li: employment of qualification $\mathrm{i}$ in the non-business sector 
Table 2

Optimal activity levels, optimal net exports and observed net exports (selected years).

\begin{tabular}{|c|c|c|c|c|c|c|c|c|c|c|c|c|c|c|c|}
\hline & \multicolumn{3}{|c|}{1984} & \multicolumn{3}{|c|}{1987} & \multicolumn{3}{|c|}{1990} & \multicolumn{3}{|c|}{1993} & \multicolumn{3}{|c|}{1996} \\
\hline & $\mathbf{X}$ & $\begin{array}{l}\text { B.T } \\
\text { opt }\end{array}$ & $\begin{array}{c}\text { B.T } \\
\text { obs }\end{array}$ & $\mathbf{X}$ & $\begin{array}{l}\text { B.T } \\
\text { opt }\end{array}$ & $\begin{array}{l}\text { B.T } \\
\text { obs }\end{array}$ & $\mathbf{X}$ & $\begin{array}{l}\text { B.T } \\
\text { opt }\end{array}$ & $\begin{array}{c}\text { B.T. } \\
\text { obs }\end{array}$ & $\mathbf{X}$ & $\begin{array}{l}\text { B.T } \\
\text { opt }\end{array}$ & $\begin{array}{l}\text { B.T } \\
\text { obs }\end{array}$ & $\mathbf{X}$ & $\begin{array}{l}\text { B.T } \\
\text { opt }\end{array}$ & $\begin{array}{l}\text { B.T } \\
\text { obs }\end{array}$ \\
\hline Agric \& Fishing & 1.34 & - & - & 1.35 & - & - & 1.62 & 2.8 & - & 1.64 & 32.7 & - & 1.11 & - & - \\
\hline Food process & $2.25 *$ & 26.6 & - & 1.70* & 9.8 & 1.3 & 1.70* & 14.1 & - & 0.00 & - & 5.3 & 1.70* & 5.6 & - \\
\hline Const material & $2.21 *$ & 3.8 & - & 1.68* & 1.9 & - & 1.68* & 4.0 & 1.5 & $1.68 *$ & 2.8 & 0.2 & $1.68 *$ & 3.4 & 0.1 \\
\hline Mechan \& Elect & $1.28 *$ & - & - & 1.68* & - & - & 1.68* & - & - & 1.68* & - & - & 1.68* & - & - \\
\hline Chem \& Rubb & $1.61 *$ & - & - & 1.42* & - & - & 1.42* & - & - & 0.00 & - & - & $1.42 *$ & - & - \\
\hline Text \& Leather & 0.00 & - & - & 0.00 & - & 6.0 & 0.00 & - & 14.0 & 0.00 & - & 20.2 & 0.51 & - & 29.2 \\
\hline Other Manuf & 0.00 & - & - & $1.26 *$ & - & - & $1.26 *$ & - & - & $1.33 *$ & - & - & $1.26 *$ & - & - \\
\hline Mining & $1.43 *$ & - & 2.6 & 1.37* & - & 2.6 & 1.22* & - & 0.8 & 1.33* & 1.7 & 0.5 & 0.00 & - & 2.3 \\
\hline Hydrocarbons & $1.43 *$ & 2.8 & 30.0 & $1.37 *$ & 3.9 & 16.5 & $1.22 *$ & - & 8.0 & $1.33 *$ & $\mathbf{0 . 0}$ & 4.0 & $1.37 *$ & - & - \\
\hline Electricity & 1.42 & n.t & n.t & 1.34 & n.t & n.t & 1.30 & n.t & n.t & 1.09 & n.t & n.t & 1.29 & n.t & n.t \\
\hline Water & 1.28 & n.t & n.t & 1.28 & n.t & n.t & 1.22 & n.t & n.t & 1.20 & n.t & n.t & 1.21 & n.t & n.t \\
\hline Construction & 1.17 & n.t & n.t & 1.22 & n.t & n.t & 1.13 & n.t & n.t & 1.17 & n.t & n.t & 1.20 & n.t & n.t \\
\hline Transp \&Comm & $1.43 *$ & 8.5 & 21.0 & $1.37 *$ & 10.0 & 16.6 & $1.22 *$ & 9.2 & 17.0 & 1.33* & 8.9 & 20.1 & $1.37 *$ & 12.5 & $\mathbf{1 7 . 6}$ \\
\hline Hot \& Tourism & $1.43 *$ & 15.2 & 46.4 & $1.37 *$ & 27.6 & 56.3 & $1.22 *$ & 26.8 & 56.3 & $1.33 *$ & 17.1 & 49.7 & $1.37 *$ & 26.2 & 48.0 \\
\hline Other Services & $1.43 *$ & 43.2 & - & $1.37 *$ & 47.0 & 0.7 & $1.22 *$ & 43.2 & 2.5 & $1.33 *$ & 36.9 & - & $1.37 *$ & 52.2 & 2.9 \\
\hline $\begin{array}{c}\text { Domestic Final } \\
\text { Demand }\end{array}$ & & 1.16 & & & 1.22 & & & 1.13 & & & 1.17 & & & 1.20 & \\
\hline
\end{tabular}

$\mathrm{X}=$ Optimal activity levels. (observed level $=1$ ),

$*=$ Sectors with full capacity utilization.

B.T opt. = Optimal net exports in \% of total optimal positive net exports (a minus denotes a deficit)

B.T obs. $=$ Observed net exports in $\%$ of total observed positive net exports (a minus denotes a deficit)

n.t $=$ non-tradable 


\section{Table 3}

Shadow prices of labor, capital and foreign trade deficit (1983-1996).

\begin{tabular}{|l|c|c|c|c|c|c|c|c|}
\hline & $\mathbf{t}$ & $\mathbf{w 1}$ & $\mathbf{w 2}$ & $\mathbf{W 3}$ & $\mathbf{w 4}$ & $\mathbf{w 5}$ & $\mathbf{r}$ & $\boldsymbol{\varepsilon}$ \\
\hline $\mathbf{1 9 8 3}$ & 1.20 & 1.610 & 1.610 & 1.610 & 1.610 & 1.610 & 0.22 & 0.78 \\
\hline $\mathbf{1 9 8 4}$ & 1.16 & 2.050 & 2.050 & 2.050 & 2.050 & 2.050 & 0.17 & 0.77 \\
\hline $\mathbf{1 9 8 5}$ & 1.22 & 2.840 & 2.840 & 2.840 & 2.840 & 2.840 & 0.13 & 0.73 \\
\hline $\mathbf{1 9 8 6}$ & 1.24 & 2.270 & 2.270 & 2.270 & 2.270 & 2.270 & 0.14 & 0.77 \\
\hline $\mathbf{1 9 8 7}$ & 1.22 & 2.530 & 2.530 & 2.530 & 2.530 & 2.530 & 0.12 & 0.75 \\
\hline $\mathbf{1 9 8 8}$ & 1.20 & 1.860 & 1.890 & 1.890 & 1.890 & 1.890 & 0.16 & 0.78 \\
\hline $\mathbf{1 9 8 9}$ & 1.14 & 2.220 & 2.220 & 2.220 & 2.220 & 2.220 & 0.12 & 0.78 \\
\hline $\mathbf{1 9 9 0}$ & 1.13 & 2.960 & 2.960 & 2.960 & 2.960 & 2.960 & 0.09 & 0.75 \\
\hline $\mathbf{1 9 9 1}$ & 1.14 & 3.110 & 3.110 & 3.110 & 3.110 & 3.110 & 0.08 & 0.72 \\
\hline $\mathbf{1 9 9 2}$ & 1.15 & 3.140 & 3.140 & 3.140 & 3.140 & 3.140 & 0.10 & 0.73 \\
\hline $\mathbf{1 9 9 3}$ & 1.17 & 3.170 & 3.170 & 3.170 & 3.170 & 3.170 & 0.11 & 0.72 \\
\hline $\mathbf{1 9 9 4}$ & 1.20 & 3.170 & 3.360 & 3.360 & 3.360 & 3.360 & 0.10 & 0.69 \\
\hline $\mathbf{1 9 9 5}$ & 1.17 & 2.500 & 3.440 & 3.440 & 3.440 & 3.440 & 0.10 & 0.72 \\
\hline $\mathbf{1 9 9 6}$ & 1.20 & 2.370 & 3.410 & 3.410 & 3.410 & 3.410 & 0.13 & 0.73 \\
\hline
\end{tabular}

Units: $t$ is the optimal expansion of domestic final demand (the observed level equals 1 ), w1 to w5, the shadow prices of labor by level of qualification, are in 1000 DT / year,

$r$ is a weighted average of sectoral rates of return expressed in dinars of returns per dinar of capital stock, $\varepsilon$, the shadow price of the trade deficit, is also in dinars per dinar of trade deficit. 
Table 4

Industrial distribution of the wage bill for qualified labor and rates of return on qualified labor (1983-1996).

\begin{tabular}{|c|c|c|c|c|c|c|c|}
\hline & 1983 & 1984 & 1985 & 1986 & 1987 & 1988 & 1989 \\
\hline Agric \& Fishing & $23.5 \%$ & $22.1 \%$ & $21.4 \%$ & $21.2 \%$ & $20.9 \%$ & $21.0 \%$ & $20.4 \%$ \\
\hline Food process & $2.9 \%$ & $2.9 \%$ & $2.9 \%$ & $2.8 \%$ & $2.9 \%$ & $3.2 \%$ & $3.4 \%$ \\
\hline Const material & $2.7 \%$ & $2.7 \%$ & $3.0 \%$ & $2.9 \%$ & $3.0 \%$ & $3.0 \%$ & $3.0 \%$ \\
\hline Mechan \& Elect & $2.9 \%$ & $2.9 \%$ & $3.3 \%$ & $3.0 \%$ & $3.0 \%$ & $3.0 \%$ & $3.7 \%$ \\
\hline Chem \& Rubb & $1.7 \%$ & $1.7 \%$ & $1.8 \%$ & $1.8 \%$ & $1.9 \%$ & $1.9 \%$ & $2.0 \%$ \\
\hline Text \& Leather & $13.1 \%$ & $13.7 \%$ & $12.3 \%$ & $11.3 \%$ & $10.4 \%$ & $9.9 \%$ & $9.6 \%$ \\
\hline Other Manuf & $3.3 \%$ & $3.6 \%$ & $3.6 \%$ & $3.7 \%$ & $3.7 \%$ & $3.7 \%$ & $3.7 \%$ \\
\hline Mining & $1.6 \%$ & $1.5 \%$ & $1.3 \%$ & $1.3 \%$ & $1.2 \%$ & $1.2 \%$ & $1.1 \%$ \\
\hline Hydrocarbons & $1.4 \%$ & $1.3 \%$ & $1.4 \%$ & $1.3 \%$ & $1.5 \%$ & $1.6 \%$ & $1.5 \%$ \\
\hline Electricity & $3.2 \%$ & $3.0 \%$ & $3.0 \%$ & $3.0 \%$ & $3.0 \%$ & $3.0 \%$ & $3.0 \%$ \\
\hline Water & $1.3 \%$ & $1.4 \%$ & $1.5 \%$ & $1.6 \%$ & $1.6 \%$ & $1.7 \%$ & $1.7 \%$ \\
\hline Construction & $2.3 \%$ & $2.4 \%$ & $2.4 \%$ & $2.4 \%$ & $2.3 \%$ & $2.4 \%$ & $2.5 \%$ \\
\hline Transp \&Comm & $6.2 \%$ & $6.1 \%$ & $6.1 \%$ & $6.1 \%$ & $6.1 \%$ & $6.2 \%$ & $6.1 \%$ \\
\hline Hot \& Tourism & $4.7 \%$ & $4.5 \%$ & $4.4 \%$ & $4.4 \%$ & $4.5 \%$ & $4.6 \%$ & $4.5 \%$ \\
\hline Other Services & $29.2 \%$ & $30.3 \%$ & $31.8 \%$ & $33.1 \%$ & $33.8 \%$ & $33.6 \%$ & $33.8 \%$ \\
\hline $\begin{array}{l}\text { Total wage bill for } \\
\text { qualified labor* }\end{array}$ & 636.9 & 653.6 & 603.0 & 651.7 & 566.0 & 644.5 & 596.4 \\
\hline $\begin{array}{c}\text { Total wage bill for } \\
\text { qualified labor } \\
\text { /GDP } \\
\end{array}$ & $7.5 \%$ & $7.2 \%$ & $6.5 \%$ & $7.1 \%$ & $5.9 \%$ & $6.6 \%$ & $5.9 \%$ \\
\hline $\begin{array}{c}\text { Average rate of } \\
\text { return on } \\
\text { qualified labor } \\
\end{array}$ & $-66 \%$ & $-55 \%$ & $-31 \%$ & $-48 \%$ & $-32 \%$ & $-55 \%$ & $-42 \%$ \\
\hline
\end{tabular}

*Total wage bill for qualified labor: in 1,000,000 dinars of 1990 
Table 4 (Con'd)

Industrial distribution of the wage bill for qualified labor and rates of return on qualified labor (1983-1996).

\begin{tabular}{|c|c|c|c|c|c|c|c|}
\hline & 1990 & 1991 & 1992 & 1993 & 1994 & 1995 & 1996 \\
\hline Agric \& Fishing & $20.0 \%$ & $19.3 \%$ & $18.4 \%$ & $18.2 \%$ & $17.9 \%$ & $17.3 \%$ & $17.0 \%$ \\
\hline Food process & $3.3 \%$ & $3.2 \%$ & $3.2 \%$ & $3.3 \%$ & $3.2 \%$ & $3.3 \%$ & $3.5 \%$ \\
\hline Const material & $2.9 \%$ & $3.0 \%$ & $2.8 \%$ & $2.7 \%$ & $2.5 \%$ & $2.4 \%$ & $2.4 \%$ \\
\hline Mechan \& Elect & $3.6 \%$ & $3.6 \%$ & $3.6 \%$ & $3.6 \%$ & $3.6 \%$ & $3.5 \%$ & $3.6 \%$ \\
\hline Chem \& Rubb & $2.1 \%$ & $2.1 \%$ & $2.1 \%$ & $2.3 \%$ & $2.8 \%$ & $2.8 \%$ & $2.9 \%$ \\
\hline Text \& Leather & $9.6 \%$ & $9.9 \%$ & $10.5 \%$ & $10.4 \%$ & $10.2 \%$ & $9.8 \%$ & $9.5 \%$ \\
\hline Other Manuf & $3.6 \%$ & $3.5 \%$ & $3.7 \%$ & $3.8 \%$ & $3.9 \%$ & $4.0 \%$ & $4.2 \%$ \\
\hline Mining & $1.0 \%$ & $0.9 \%$ & $0.8 \%$ & $0.7 \%$ & $0.7 \%$ & $0.6 \%$ & $0.6 \%$ \\
\hline Hydrocarbons & $1.5 \%$ & $1.5 \%$ & $1.5 \%$ & $1.4 \%$ & $1.3 \%$ & $1.3 \%$ & $1.2 \%$ \\
\hline Electricity & $2.9 \%$ & $2.8 \%$ & $2.7 \%$ & $2.7 \%$ & $2.6 \%$ & $2.5 \%$ & $2.4 \%$ \\
\hline Water & $1.7 \%$ & $1.7 \%$ & $1.7 \%$ & $1.7 \%$ & $1.6 \%$ & $1.6 \%$ & $1.6 \%$ \\
\hline Construction & $2.6 \%$ & $2.7 \%$ & $2.8 \%$ & $3.0 \%$ & $3.1 \%$ & $3.1 \%$ & $3.3 \%$ \\
\hline Transp \&Comm & $6.0 \%$ & $5.9 \%$ & $6.0 \%$ & $6.0 \%$ & $5.9 \%$ & $5.8 \%$ & $5.8 \%$ \\
\hline Hot \& Tourism & $4.5 \%$ & $4.4 \%$ & $4.2 \%$ & $4.3 \%$ & $4.3 \%$ & $4.7 \%$ & $4.8 \%$ \\
\hline Other Services & $34.7 \%$ & $35.6 \%$ & $36.3 \%$ & $36.2 \%$ & $36.6 \%$ & $37.0 \%$ & $37.3 \%$ \\
\hline $\begin{array}{c}\text { Total wage bill for } \\
\text { qualified labor* }\end{array}$ & 697.7 & 655.8 & 816.6 & 752.9 & 868.2 & 805.4 & 948.3 \\
\hline $\begin{array}{c}\text { Total wage bill for } \\
\text { qualified labor } \\
\text { /GDP }\end{array}$ & $6.5 \%$ & $5.8 \%$ & $6.7 \%$ & $6.1 \%$ & $6.8 \%$ & $6.2 \%$ & $6.8 \%$ \\
\hline $\begin{array}{l}\text { Average rate of } \\
\text { return on } \\
\text { qualified labor }\end{array}$ & $-31 \%$ & $-20 \%$ & $-32 \%$ & $-25 \%$ & $-29 \%$ & $-20 \%$ & $-30 \%$ \\
\hline
\end{tabular}

*Total wage bill for qualified labor: in 1,000,000 dinars of 1990 
Table 5

Domestic Final Demand (D.F.D) growth by sources (\%)

\begin{tabular}{|l|c|c|c|c|}
\hline & 1983-1996 & 1983-1986* $^{*}$ & 1986-1991*** $^{*}$ & 1991-1996*** \\
\hline D.F.D & 1.90 & -1.07 & 2.55 & 3.28 \\
\hline - L5 & 0.16 & 0.21 & 0.08 & 0.11 \\
- L4 & 0.27 & 0.25 & 0.16 & 0.21 \\
- L3 & 0.31 & 0.42 & 0.49 & 0.18 \\
- L2 & 2.36 & 3.03 & 3.08 & 1.85 \\
- L1 & 0.43 & 1.27 & 1.26 & -0.88 \\
- Capital & -0.77 & -4.76 & -2.98 & 2.98 \\
- Deficit & -0.85 & -1.48 & 0.45 & -1.18 \\
\hline
\end{tabular}

$* 6^{\text {th }}$ five-year plan of development (1982-1986)

$* * 7^{\text {th }}$ five-year plan of development (1987-1991)

$* * * 8^{\text {th }}$ five-year plan of development (1992-1996) 


\section{Liste des publications au CIRANO*}

Série Scientifique / Scientific Series (ISSN 1198-8177)

2002s-26 Restructuring and Economic Performance: The Experience of the Tunisian Economy / Sofiane Ghali and Pierre Mohnen

2002s-25 What Type of Enterprise Forges Close Links With Universities and Government Labs? Evidence From CIS 2 / Pierre Mohnen et Cathy Hoareau

2002s-24 Environmental Performance of Canadian Pulp and Paper Plants : Why Some Do Well and Others Do Not? / Julie Doonan, Paul Lanoie et Benoit Laplante

2002s-23 A Rule-driven Approach for Defining the Behavior of Negotiating Software Agents / Morad Benyoucef, Hakim Alj, Kim Levy et Rudolf K. Keller

2002s-22 Occupational Gender Segregation and Women's Wages in Canada: An Historical Perspective / Nicole M. Fortin et Michael Huberman

2002s-21 Information Content of Volatility Forecasts at Medium-term Horizons / John W. Galbraith et Turgut Kisinbay

2002s-20 Earnings Dispersion, Risk Aversion and Education / Christian Belzil et Jörgen Hansen

2002s-19 Unobserved Ability and the Return to Schooling / Christian Belzil et Jörgen Hansen

2002s-18 Auditing Policies and Information Systems in Principal-Agent Analysis / MarieCécile Fagart et Bernard Sinclair-Desgagné

2002s-17 The Choice of Instruments for Environmental Policy: Liability or Regulation? / Marcel Boyer, Donatella Porrini

2002s-16 Asymmetric Information and Product Differentiation / Marcel Boyer, Philippe Mahenc et Michel Moreaux

2002s-15 Entry Preventing Locations Under Incomplete Information / Marcel Boyer, Philippe Mahenc et Michel Moreaux

2002s-14 On the Relationship Between Financial Status and Investment in Technological Flexibility / Marcel Boyer, Armel Jacques et Michel Moreaux

2002s-13 Modeling the Choice Between Regulation and Liability in Terms of Social Welfare / Marcel Boyer et Donatella Porrini

2002s-12 Observation, Flexibilité et Structures Technologiques des Industries / Marcel Boyer, Armel Jacques et Michel Moreaux

2002s-11 Idiosyncratic Consumption Risk and the Cross-Section of Asset Returns / Kris Jacobs et Kevin Q. Wang

2002s-10 The Demand for the Arts / Louis Lévy-Garboua et Claude Montmarquette

2002s-09 Relative Wealth, Status Seeking, and Catching Up / Ngo Van Long, Koji Shimomura

2002s-08 The Rate of Risk Aversion May Be Lower Than You Think / Kris Jacobs

2002s-07 A Structural Analysis of the Correlated Random Coefficient Wage Regression Model / Christian Belzil et Jörgen Hansen

* Consultez la liste complète des publications du CIRANO et les publications elles-mêmes sur notre site Internet : 
2002s-06 Information Asymmetry, Insurance, and the Decision to Hospitalize / Åke Blomqvist et Pierre Thomas Léger

2002s-05 Coping with Stressful Decisions: Individual Differences, Appraisals and Choice / Ann-Renée Blais

2002s-04 A New Proof Of The Maximum Principle / Ngo Van Long et Koji Shimomura

2002s-03 Macro Surprises And Short-Term Behaviour In Bond Futures / Eugene Durenard et David Veredas

2002s-02 Financial Asset Returns, Market Timing, and Volatility Dynamics / Peter F. Christoffersen et Francis X. Diebold

2002s-01 An Empirical Analysis of Water Supply Contracts / Serge Garcia et Alban Thomas

2001s-71 A Theoretical Comparison Between Integrated and Realized Volatilities Modeling / Nour Meddahi

2001s-70 An Eigenfunction Approach for Volatility Modeling / Nour Meddahi

2001s-69 Dynamic Prevention in Short Term Insurance Contracts / M. Martin Boyer et Karine Gobert

2001s-68 Serial Cost Sharing in Multidimensional Contexts / Cyril Téjédo et Michel Truchon

2001s-67 Learning from Strike / Fabienne Tournadre et Marie-Claire Villeval

2001s-66 Incentives in Common Agency / Bernard Sinclair-Desgagné

2001s-65 Detecting Mutiple Breaks in Financial Market Volatility Dynamics / Elena Andreou et Eric Ghysels

2001s-64 Real Options, Preemption, and the Dynamics of Industry Investments / Marcel Boyer, Pierre Lasserre, Thomas Mariotti et Michel Moreaux

2001s-63 Dropout, School Performance and Working while in School: An Econometric Model with Heterogeneous Groups / Marcel Dagenais, Claude Montmarquette et Nathalie Viennot-Briot

2001s-62 Derivatives Do Affect Mutual Funds Returns : How and When? / Charles Cao, Eric Ghysels et Frank Hatheway

2001s-61 Conditional Quantiles of Volatility in Equity Index and Foreign Exchange Data / John W. Galbraith, Serguei Zernov and Victoria Zinde-Walsh

2001s-60 The Public-Private Sector Risk-Sharing in the French Insurance "Cat. Nat. System" / Nathalie de Marcellis-Warin et Erwann Michel-Kerjan

2001s-59 Compensation and Auditing with Correlated Information / M. Martin Boyer et Patrick González

2001s-58 Resistance is Futile: An Essay in Crime and Commitment / M. Martin Boyer

2001s-57 The Unreliability of Output Gap Estimates in Real Time / Athanasios Orphanides et Simon van Norden

2001s-56 Exact Nonparametric Two-Sample Homogeneity Tests for Possibly Discrete Distributions / Jean-Marie Dufour et Abdeljelil Farhat

2001s-55 Les coûts de la réglementation : une revue de la littérature / Robert Gagné, Paul Lanoie, Pierre-Carl Micheud et Michel Patry

2001s-54 Testing for structural Change in the Presence of Auxiliary Models / Eric Ghysels et Alain Guay 